\title{
The Intellectual Legacy of Prof. Claude Sumner in Western, Ethiopian and African Thought*
}

\author{
Odomaro Mubangizi ${ }^{\dagger}$
}

\section{Introduction}

First of all, I wish to express my deep gratitude to Professor Bekele Gutema for inviting me to participate in this workshop, a centenary memorial of Professor Claude Sumner's contribution to Ethiopian Philosophy. I appreciate the effort by Addis Ababa University, Department of Philosophy, The Ethiopian Journal of the Social Sciences and Humanities (EJOSSAH), and the Ethiopian Academy of Sciences (EAS) in hosting this workshop. This is indeed a fitting tribute to Professor Claude Sumner, who dedicated his entire life to the pursuit of wisdom.

This workshop is taking place during a critical juncture in the social, political and economic history of Ethiopia. There are momentous changes taking in Ethiopia, and so it is crucial that students of philosophy and those who have made philosophy their way of life reflect deeply on deeper issues that affect society. The African continent is also undergoing rapid changes and there is much talk about "Africa rising." Does philosophy have a contribution in such hopeful narratives? What inspiration can we draw from Professor Claude Sumner with regard to the role of philosophy in the public sphere? What role can philosophy play in the social, political and economic transformation of Africa in general and Ethiopia in particular, and hence contributing to the African renaissance? Even though this workshop is not directly concerned about these issues, it is important to have them at the back of our minds.

Few scholars have traversed such a vast intellectual terrain as Prof. Claude Sumner, hence the enormous challenge of characterizing his thought and intellectual legacy. I deliberately used "intellectual legacy" to avoid pigeon-holing him in one discipline, since his writings cover diverse areas as poetry, spirituality, philosophical anthropology, logic, ethics, African philosophy, Ethiopian

\footnotetext{
* Keynote Speech-Workshop: Revisiting Professor Claude Sumner's Contribution to Ethiopian Philosophy: A Centenary Memorial, $8^{\text {th }}$ July, 2019

${ }^{\dagger}$ Associate Professor, Dean of Philosophy Department, Institute of Philosophy and Theology, Urbaniana University, Rome, Italy, email: odomarom@gmail.com, Tel. +251978686966, P. O. Box 21322/ Addis Ababa.
}

This work is licensed to the publisher under the Creative Commons Attribution-NonCommercialNoDerivs License. 


\section{Odomaro Mubangizi}

Philosophy, Oromo Philosophy, Oromo Folktales and proverbs. Nevertheless, Prof. Sumner is generally and widely celebrated as a philosopher who broke new ground in African and Ethiopian philosophy. The reason for making a distinction between African and Ethiopian is the fact that the latter has a distinct and long written philosophical tradition that is unique from the rest of Africa.

A lot has been written by and about Prof. Sumner. This brief sketch is essentially a tribute to his contribution to philosophy. A brief biography of Sumner will be presented, followed by his contribution to Western, African and Ethiopian scholarship. By way of conclusion, some questions will be raised on what next for African and Ethiopian philosophies.

\section{A Brief Biography of Prof. Claude Sumner}

Professor Claude Sumner was born on July $10^{\text {th }} 1919$ in Canada. His grandfather Louis-Arthur Prud'homme was a judge. At the age of twenty he obtained a B.A. in philosophy from the University of Manitoba in 1939. In 1945 Sumner did his studies in Montreal at the Faculty of Theology and Philosophy earning a Licentiate in Philosophy, and a Licentiate in Theology in 1952. Then he did his M.A. in English literature at the University of Montreal in 1949. He completed his PhD in linguistics at the University of Montreal in 1952. In 1953 he came to Ethiopia to begin a long teaching career at the University College of Addis Ababa, where he taught for more than 40 years. Among other accomplishments, he chaired the Department of Philosophy and also became a Professor Emeritus (Turenne, 2016, p. 53).

In the field of scholarship, Sumner's literary output is marched by a few. He published 49 books and 191 articles on various topics. A vast collection of articles, doctoral thesis as well as books have also been published on his work. His works have been published in twelve languages: Amharic, Arabic, Dutch, English, French, Frisian, German, Greek, Italian, Oromo, Portuguese, and Spanish. This makes him truly a global intellectual icon. As to his embracing a culture foreign to his, he used to refer to himself as "Canadian by birth but an Ethiopian by choice." Did Sumner have extra time for other concerns besides academics? Absolutely. He was socially committed to several causes including justice, development, cultural promotion, as well as pastoral engagement. For instance in 1971 he was head of the Cultural Committee of International Organization for Justice and Development (IOJD), Vice-President of the Foundation for the Protection of Health and Environment (1973), Vice-President of the Foundation for Health and Human Rights (1983). 
In terms of his priestly duties, he set aside some time to preach retreats each year when he returned to Canada. But also for over 30 years he conducted an Ecumenical Biblical Seminar that included participants from the Ethiopian Orthodox Christians as well as Anglicans. Many religious men and women in Addis Ababa still remember those seminars.

Sumner's great accomplishments were handsomely rewarded by several institutions and organizations. Just few will suffice: Gudina Tumsa Foundation in Addis Ababa, for the promotion and diffusion of Oromo culture, including Prof. Sumner's works on Oromo wisdom (1992); Honorary Doctorate Degree from Northland Open University, Windsor, England (1986); Honorary Distinguished Professor of Philosophy at the International Open Distance University and EURAM College (1984); Foundation of the Sumner International Centre for African Studies (SICAS) in the Netherlands (1983).

Of special importance is the contribution Prof. Sumner made to the promotion of African philosophy. To this end he organized the first Pan-African Seminar on African Philosophy in Addis Ababa in 1976. Proceedings of this conference were published by him. Then followed numerous public lectures on African and Ethiopian philosophies in several African universities and outside Africa. Among distinguished African philosophers who have been impressed by Prof. Sumner is Odera Oruka. Consider how Oruka characterizes Sumner:

Given so far what he has done in unearthing and analyzing Ethiopian philosophy, Prof. Sumner is, without doubt, a combination of Plato and Aristotle of Ethiopia. What he has done to Ethiopia in the field of philosophy can, in all fairness, be as important and original as what Plato and Aristotle did for Greece. I can foresee no scholar of Ethiopian philosophy surpassing or ignoring Sumner's contributions within the range of the next one hundred years (1999).

And yet despite what Prof. Oruka has said above, Prof. Sumner's scholarly works are not widely known and appreciated in the African continent as would have been expected. One reason could be the fact that the country that he studied very closely, was by then not very much known in the rest of Africa as far philosophical discourse is concerned. The other possible reason could be the very status of philosophical knowledge in Africa, as a discipline that is not very much highly regarded except in catholic major seminaries or institutes, where it is a compulsory academic requirement. 


\section{Odomaro Mubangizi}

\section{Sumner's Contribution to Western Scholarship}

Prof. Sumner started his intellectual journey in a Western scholarly tradition, in Canada to be specific. As his academic qualifications demonstrate he was schooled in Western philosophy, theology and linguistics. But what is interesting is that for his doctoral studies he wrote a thesis on Ethiopian linguistics (1999, p. 2). Due to his broad humanistic Jesuit education, his works easily appeal to a wide audience: philosophers, historians, anthropologists, philologists, poets, and theologians (1999, pp. 2-3).

Sumner's started off his scholarly publishing with Eight Types of Ethical Theory in 1952. In this work he dwells on the development of moral thought. He studies key philosophers such as Plato, Aristotle, Augustine, Aquinas, Spinoza, Hume and Kant (1974, p. 7). Sumner rightly links ethics and philosophical anthropology when he argues that "...the problems of morality are the problems of man" (1974, p. 7). It is therefore not surprising that his major first scholarly works from 1973 to 1974 dealt with philosophical anthropology or philosophy of man in three volumes. These works are: Volume I from the Upanisads to the British Empiricism (1973); Volume II from Kant to the Situation in 1963 (1974); Volume III Related Writings (1975). In these works Sumner argues that human beings share essentially common elements making a case for unity of all people, despite diverse religious and ideological beliefs. His methodology can be described as "documentary-synthetic." He carefully and accurately records the thoughts of thinkers and discerns the common thread to create a synthesis.

Volume I, From the Upanisads to the British Empiricists, covers the concept of man according to Plato, Aristotle, Augustine, Thomas Aquinas, Bonaventure, John Duns Scotus, William of Ockham, Cajetan, Francis Bacon, Rene Descartes, Blaise Paschal, Baruch Spinoza, Leibniz, John Locke, George Berkeley and David Hume (1974, p. 7). In each of the thinkers he meticulously discusses life and works on psychology, general philosophy, human nature (mind and body, soul, etc.). In his treatment of these thinkers he is encyclopaedic, giving compressed details. The thinkers in this volume cover the historical periods in philosophy of history labeled as: Ancient, medieval and modern.

Volume II From Kant to the Situation in 1963, covers contemporary thinkers such as Immanuel Kant, Hegel, Karl Marx, Engels, Arthur Schopenhauer, Nietzsche, William James, John Dewey, Henri Bergson, Teilhard De Chardin (Sumner, 1963, pp. 1-347). Then follows the philosophy of man in the $20^{\text {th }}$ century covering trends as phenomenology (Husserl and Heidegger), personalism, existentialism, organism, and logical positivism. The method of presentation is similar to that of Volume I life of the thinker, views on man, soul and body. What I 
find very innovative methodologically as far as volume II is concerned is chapter XXII-Philosophy of Man: 1963. Prof. Sumner asked a group of 27 German philosophers ten question in 1963 (287-288). First, what are the major trends of philosophy in Germany? Second, what is your concept of man? Third, does the freedom of man exist? Four, Does the human person possess a special inalienable dignity of its own? Five, what is the meaning of life? Six, What impact does the theory of evolution have on the philosophy of man? Seven, What impact do experimental psychology and psychoanalysis have on the same philosophy of man? Eight, what is the present situation and future of man in a society that is becoming more and more technological? Nine, What are the values of the past that still have meaning today? Ten, what are the present-day values which are significant for the preservation and development of culture? Space does not allow that I provide the answers to these questions. But it is important to appreciate how rigorous Prof. Sumner was in his philosophical reflection and insightfully posing questions. After all, it is suggested that philosophy is more about raising questions than providing answers.

And finally, Volume III Related Readings, offers excerpts from the main thinkers discussed in Volumes I \& II. Sumner makes a poignant comment that commentaries by an author "...is no substitute for the reader's and the student's contact with the original work of a given thinker" $(1975$, p. 1).

\section{Sumner's Contribution to African and Ethiopian Scholarship}

One may wonder as to why Prof. Sumner ventured into the murky waters of a highly contested discipline of African and Ethiopian philosophies, when some would consider him an "outsider." There had been a raging debate on whether there is such a thing as African philosophy and a related question of who is an African philosopher. Sumner, without theoretically engaging in such a debate, went ahead to organize the first pan-African conference on African philosophy, and to give numerous public lectures on the same discipline all over the world. In this initiative he was gradually learning to appreciate a world-view foreign to him. But since he was a philosopher by training he had the necessary tools to detect what could be philosophical elements in African and Ethiopian value systems and modes of thought.

The clue that can help us understand why Sumner ventured into African and Ethiopian philosophy is a comment by Patricia Johnson: "A consistent Ethic of justice, peace, unity, and love permeates the work of Claude Sumner, and become a dynamic of restoration available to any who read it" (Abba Salama Volume III). Prof. Sumner must have felt that it was a matter of justice to uncover the hidden 


\section{Odomaro Mubangizi}

treasures of African and Ethiopian philosophy in the sands of history. His whole work, though not overtly polemical in defense of African and Ethiopian philosophy, is a major assertion of the existence of African and Ethiopian philosophies.

His commitment to promoting scholarly work on African Philosophy is evidenced by his being on the Editorial Board of The Journal of African Religion and Philosophy published by Makerere University. Similarly, his commitment to Ethiopian studies can be discerned from his availability to serve on the Advisory Committee of the Ethiopian Review of Cultures, since its inception in the early 1990s. He also regularly contributed scholarly articles to the Review: "The rationalism of Zera Yacob," Ethiopian Review of Cultures, Vol. VIII, 2000; "Ethiopianization of courses of philosophy," Ethiopian Review of Cultures, Special Issue, 1994-1995; "The notion of the human being in Ethiopian written philosophy and in Oromo wisdom literature," Ethiopian Review of Cultures, Special Issue 1996-1997. In these brief articles, Sumner summarized the main lines of his philosophical thought on African and Ethiopian philosophy. The problems he was struggling with are: philosophical anthropology in Ethiopian written philosophy and in Oromo wisdom literature; morality in Ethiopian written philosophy and in Oromo wisdom literature (Sumner, 1994-1995, p. 309). On Western and African/Ethiopian philosophy he posed the following questions - should the course of philosophy present only the Western approach and content? Or only the African/Ethiopian? Ethiopian philosophy-should it constitute a separate course? African background? - should the course of Ethiopian philosophy be a closed unit or should it be presented against its African background?: "The Ethiopian sources of African philosophy" or "African philosophy and its Ethiopian Expression?" Philosophical and sapiential literature-should Ethiopian philosophy be represented only in its written form? Or should it include oral sapiential literature, proverbs, songs, folktales?

The works of Sumner on African and Ethiopian philosophy are an attempt to answer all these questions. In The Book of the Wise Philosophers he demonstrated how some Greek philosophy elements found their way into Ethiopia. In The Treatise of Zera Yacob and of Walda Haywat, he demonstrated how what the modern Western era of rationalism with Descartes has its equivalent in Ethiopia. In Living Springs of Wisdom and Philosophy, he addresses the problems of African philosophy on its nature, sources and themes. With regard to the question of two extremes of Africentrism and Eurocentrism, Sumner opted for anthropocentrism: "Man, the human being, is both the same all over the world, and 
different from one place to another, from one century to another" (199-1995, p. $315)$.

With regard to Ethiopian philosophy, Sumner argued that there are philosophies and not one philosophy. Since a good number of these works were translations and not original works, he raises a question on their philosophical merit. He answers the question thus: “...Ethiopians never translated literally...The translation is an adaptation; they add, subtract, modify. In other words, a foreign work becomes indigenous, not through originality of invention, but through originality of style" (Sumner, 1988, p. 331). A common saying is that "any translation is an interpretation."

The other great contribution to philosophical discourse by Claude Sumner is establishing the philosophical merit of African oral wisdom literature found in proverbs. He studied 1,067 Oromo proverbs, riddles and songs to establish this claim. He came to the following conclusion: "The center of Oromo anthropology is the human-being-in-situation, the person within his or her socio-economic background" (Sumner, 1997-1997, p. 194). Some illustrative proverbs will make the point clear: The first saint is the father - a father deserves priority and should be respected, venerated and obeyed even before a saint. The calves do not fear the horns of their mother - the main point here is maternal care. The Kiga of Western Uganda have similar proverbs: one who is not your mother does not look at your stomach - a mother cares by examining the stomach of her child to see if her child needs food. A bad child brings abuses to his mother-a mother is blamed for not bringing up the child well. Some proverbs have hidden epistemological value such as: Unless one travels one does not know about expatriation (Sumner, 1995, p. 176). The Kiga of Western Uganda have a related proverb: Travel helps one to see. These proverbs seem to be empiricist by orientation. Riddles can be regarded as applied logic. Consider for instance the following Oromo riddles: Born late, it outgrows its elder-Answer: the cow horn when compared with the ear; we eat together, why are you so thin-Answer: fork (1995, pp. 1064, 1073). In addition to be entertaining, both riddles and proverbs help to sharpen the mind and improve reasoning capacity, just like logic or moral dilemmas.

\section{Conclusion and Way-forward}

The intellectual legacy of Prof. Claude Sumner both in Western and African/Ethiopian thought has been established. His voluminous publications are an enduring testimony of his passion for philosophical reflection. But what is most appreciated most in Prof. Sumner is his commitment to the promotion of and elaboration on African/Ethiopian philosophy. 


\section{Odomaro Mubangizi}

African/Ethiopian philosophy still occupies a limited space in African and Western Universities. At most there is some casual mention of African philosophy during the course on philosophy. If there is such a large body of African/Ethiopian philosophy, one wonders why this school of thought cannot be fully integrated in the programs of philosophy. Just situating African/Ethiopian philosophy alongside other branches of philosophy or as an appendix does a disservice to the quest for an African renaissance. One can make an argument that as long as Africa continues to borrow ideas while neglecting her own intellectual traditions (written or oral), it will never come up with viable solutions for her social, economic, political and technological challenges.

Prof. Claude Sumner paved a way for a vigorous African/Ethiopian philosophical discourse, this needs to be continued and enhanced in a more structured way. We can even anticipate establishing universities or institutions that will be dedicated solely to the study of African/Ethiopian philosophy, following the standard epochs of ancient, medieval, modern and contemporary periods. And if there is any place where such an intellectual innovation can take place, it is Ethiopia - the land of origins and cradle of humanity. While Addis Ababa is celebrated as the Capital City of Africa, adding another label does no harm. Why not declare Addis Ababa, the Intellectual Capital of Africa, where ideas such as pan-Africanism, Afro-politanism and Ubuntu can be better articulated and disseminated? Existing institution in Addis Ababa, that are daily struggling with finding African-centered solutions, such as the AU, UNECA, IPSS, and OSSREA, can benefit immensely from Ethiopian and African philosophical discourse.

Once again thank you so much for honoring Professor Claude Sumner, and may his intellectual legacy continue to inspire many young and upcoming scholars who are fascinated by philosophical ideas and discourse, across Africa. 


\section{References}

Sumner, C. (2000). Words that lead to God. Quebéc.

Sumner, C. (1999). Living springs of wisdom and philosophy: Volume 1: Problematics of an African philosophy. Addis Ababa: Addis Ababa University.

Sumner, C. (1974). The philosophy of man: Volume I: From the Upansads to the British Empiricists. Addis Ababa: Haile Sellasie I University.

Sumner, C. (1974). The Philosophy of man: Volume II: From Kant to the situation in 1963. Addis Ababa: Central Printing Press.

Sumner, C. (1975). Volume III related reading. Addis Ababa: Central Printing Press.

Turenne, R. (2016). As I remember them...: Memoirs of a former TMS teacher. Addis Ababa.

Vos, J. (1985). An Ethiopian psychology Sumner and Jung: A cross-cultural study on aspects of Ethiopian psychology based on the philosophical research of Claude Sumner in comparison with the Western approach of Carl Gustac Jung. Oost-Souburg: Netherlands. 